\title{
Analysis of performances in white giant rabbits reared in sub-temperate climate of Kodai hills, Tamil Nadu
}

\author{
S. RAJAPANDI, N. RAMANATHAN, R. POUROUCHOTTAMANE, A.K. THIRUVENKADAN, S. RAMESH SARAVANA \\ KUMAR, P.K. PANKAJ AND A.S. RAJENDIRAN
}

\begin{abstract}
The present study was carried out at Institute Rabbit Farm of ICAR-Southern Regional Research Centre, Central Sheep and Wool Research Institute, Mannavanur, Kodaikanal, Tamil Nadu, India which is located at 2030 metre above mean sea level. The climatic conditions prevailing in the region is sub-temperate with winter temperature during night hours going below zero ${ }^{\circ} \mathrm{C}$. The objective of investigation was to find out the influence of different factors such as year, season and parity on different litter traits and pre-weaning growth of White Giant rabbits in order to come out with the best strategies for improving the productivity of these rabbits. A total of 946 records for litter size at birth (LSB) and weaning (LSW), litter weight at birth (LWB) and weaning (LWW) were collected in the period between 2000 to 2009 and the data was analyzed using General Linear Model option of SAS 9.2. The overall LSB, LSW, LWB and LWW were 7.067 $\pm 0.11,5.788 \pm 0.13,400.00 \pm 5.99 \mathrm{~g}$ and $4.877 \pm 0.10 \mathrm{~kg}$, respectively. All the litter traits varied significantly year-wise, however, they were not varying significantly parity-wise except LWW which increased progressively from first parity $(4.364 \pm 0.32 \mathrm{~kg})$ to fifth parity $(5.612 \pm 0.27 \mathrm{~kg})$. The season of kindling did not have significant role in affecting different litter traits and the values were comparable. The year, season and sex had significantly $(\mathrm{P}>0.01)$ influenced both weaning weight at six weeks and pre-weaning ADG. The growth was better in male animals as evident from higher body weight at six week age and average daily gain $(853.090 \pm 3.49 \mathrm{~g}$ and $19.123 \pm 0.08 \mathrm{~g} /$ day vs. $820.493 \pm 3.53 \mathrm{~g}$ and $18.347 \pm 0.08 \mathrm{~g} /$ day). Rabbits born during winter months gained more weight $(876.055 \pm 4.86 \mathrm{~g}$ and $19.670 \pm 0.12 \mathrm{~g} /$ day $)$ while performance of rabbits born during spring and rainy season were comparable. The significant effects of the non-genetic factors like year of kindling on all litter traits, individual weight at weaning and pre-weaning ADG, season and parity on some of the traits are indications that any future breed development strategy must take into consideration the environment by providing additional care, feed supplementation and better shelter management to the rabbits so that the full genetic potential can be realized.
\end{abstract}

KEY WORDS : Rabbit, Sub-temperate, Litter traits, Parity, Season, Growth

HOW TO CITE THIS PAPER : Rajapandi, S., Ramanathan, N., Pourouchottamane, R., Thiruvenkadan, A.K., Kumar, S. Ramesh Saravana, Pankaj, P.K. and Rajendiran, A.S. (2015). Analysis of performances in white giant rabbits reared in sub-temperate climate of Kodai hills, Tamil Nadu. Res. J. Animal Hus. \& Dairy Sci., 6(1) : 16-21.

Address for correspondence :

S. Rajapandi, Faculty of Agriculture and Animal Husbandry, Gandhi Gram Rural Institute, DINDIGUL (T.N.) INDIA

Associated Authors' :

N. Ramanathan, School of Agriculture, Gandhi Gram Central University for Rural Development, DINDIGUL (T.N.) INDIA

R. Pourouchottamane and A.S. Rajendiran, Southern Regional Research Centre, ICAR, Central Sheep and Wool Research Institute, MANNAVANUR (T.N.) INDIA

A.K. Thiruvenkadan, Department of Bio Statistics, Veterinary College and Research Institute (TANUVAS), NAMAKKAL (T.N.) INDIA

S. Ramesh Saravana Kumar, Department of Livestock Production Management, Veterinary College and Research Institute (TANUVAS), NAMAKKAL (T.N.) INDIA
}

P.K. Pankaj, Central Research Institute for Dryland Agriculture (ICAR), HYDERABAD (TELANGANA) INDIA 